\title{
A Management Plan and how it works
}

\section{Desmond Vesey-Fitzgerald}

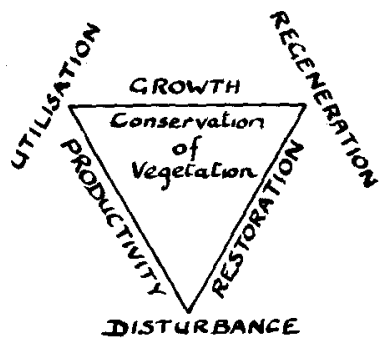

Management in a national park is the art of maintaining harmony between living things; it must work with nature, not against, if only because that is so much easier. The author suggests a three-point plan, and shows how it is applied in the Arusha National Park.

A healthy environment is the world's greatest renewable natural resource. In the context of the fine East African national parks this fact is now appreciated, and conservation has been proclaimed the first priority for management of the national heritage.

The purpose of conservation must always be to maintain or restore the pristine productivity of the diverse natural habitats. It is almost axiomatic that any undeveloped countryside-particularly if it happens to be a reserve-has been overexploited in the past and is certainly threatened by stresses in the future. Today we have the opportunity to plan and carry out a 'health service for the environment' as the first priority.

But first we need an inventory of assets and deficiencies. We must investigate and assess the imbalances before we can prescribe and administer therapeutic treatment. In land-use planning for agriculture, pastoralism, forestry and wildlife there are many common factors-conservation of soil, water, vegetation and animals-so it is not difficult to know what the essential management goals should be. But practical problems are numerous, and ecologists are few.

A natural way to resolve management problems in a national park is by a three-point plan based on the three dynamic principles of plant growth (primary productivity), animal utilisation (secondary productivity), and development of the ecosystem to bring about a sustained yield of fertility and amenity (conservation). Action therefore must prevent further disturbance, correct imbalances, and improve the state of naturalness of the many diverse habitats.

The three-point management plan must be feasible and workable with the available information, skills and funds. It is therefore devised to work with, and not against, nature, this being so much easier. At the start, guidance in recording and progress reporting is necessary. Moreover, rehabilitation will probably be costly because of previous exploitation and land misuse, and subsidies may be needed. But the plan's outstanding advantages are that the three points form a virtually self-perpetuating swinging balance, so that it largely works itself. It is the way nature worked before man interfered.

It is interesting to see how the plan is actually working out in the

The author of this article died last year, soon after this article was recieved. A tribute to him was published in Oryx, November 1974. 
fascinating Arusha National Park in Tanzania. This is a small park by African standards, with a superficial area of about 50 square miles (130 sq. $\mathrm{km}$.) but its rugged range of altitude is from 4000-15,000 feet (1200-4500 m.). Much of the mountain's original forest has been degraded or destroyed, but over 1200 plant species have been found, as well as some sixty mammals, including the big five, several rats and mice, and over 400 birds; the mountain and lake scenery is superb. Altogether the environment is not one to be trifled with, and a conservation-orientated development plan is essential.

Man-induced disturbances this century have greatly disrupted the natural harmony of this beautiful park. Pastoralists from the semiarid plains to the north burned their way to the Momela lakes, letting in the grass. Fierce fires, following the extraction of scattered timber trees, burned into the forests at Ngurdoto. Some of the land, now included in the park, was alienated for farming, which never prospered on the steep slopes; the dusty soil blew away, and the erratic rainfall was quite unsuited to agriculture. The soil fertility failed, streams dried up, the wild animals were hunted to extinction, and useless scrub and unpalatable grasses soon covered much of the mountainside. Luckily, oases of ecological tranquillity survived.

For many years Ngurdoto Crater had been a game reserve within a forest reserve, and a tiny part of the Momela estate between two little lakes had been preserved as a sanctuary. A hidden forest high on the slopes of Meru Mountain remained relatively sacrosanct because no one bothered to go there and cut it down. Then, about ten years ago, good sense and good will prevailed and it was decided to make the area a national park.

\section{Restoration}

The first job for the parks service was to restore a state of naturalness to the mountain. This is not necessarily a pristine condition. No such condition had indeed existed on the Meru volcano's very young land surface. Cores bored into the depths of the Momela lakes established the fact that the cinder-cone towering above Meru Crater was actually younger than the Egyptian pyramids. Naturalness is the healthy healing process known as plant succession whereby degraded vegetation is rehabilitated and natural productivity restored. Not only is it necessary for the indigenous plant species to survive, but the whole structure of the vegetation must be reconstructed. An intact canopy is as necessary to the health of a forest as are the microorganisms inhabiting the cool and shaded soil. The whole spectrum of plants needs to be functioning properly to achieve a healthy fertility.

Particularly in grassland the distribution of the grass species depends greatly on the nature of the soil and the drainage, which are themselves largely functions of the vegetation cover. Exposed soil gets baked by the sun, swept by wind and eroded by rain. It is very true that every plant in the park is there because of a variety of everchanging circumstances - changes in time and space in the course of plant succession and species competition; some understanding of all this is necessary for successful management. Diversity has always 
been an essential part of the history of naturalness; it is how evolution has worked since life began.

In a national park both browsing and grazing animals need to be catered for. In East Africa, the indigenous animals are indeed the gardeners, and too much grazing is just as bad as too much growth. The native animals, by mowing the grass and thinning the bush, keep the vegetation in a state of perennial youth. Ecological tensions between the growth of grass and trees are eased, and the animal populations adapted to the changing vegetation. Plant succession is stimulated and the natural productivity of the environment restored.

Man-induced disturbances upset the harmony of naturalness and the course of plant succession, and symptoms of disturbance are usually not hard to discern. But to correct the imbalances is often difficult. Overburning for example has been rampant in the park, but preventing fires is no real solution, and anyhow seldom possible. No seedling trees can thrive when choked by unburnt grass. Sooner or later the grass will burn and fierce fires will destroy all the young trees, and, even worse, eat further into the standing forest. The proper procedure is to prescribe a patch-burn of the ungrazed grass, this keeps the fire hazard low, while improving the grazing and preventing the destruction of young trees and shrubs.

Management, then, is the art of maintaining harmony between living things. Monitoring is an essential service in scientific management, a means of scanning the environment in order to assess the conservation priorities for development. Inspection and inquiry, recording and reporting, therefore, occupy a central position in the three-point management plan.

First, attention has to be given to Regeneration, the productivity of growth. The growth potential of grass, shrubs and trees must be assessed and Disturbances removed. Fire is a major disturbance to progressive growth, but patch-burning can effectively restore the harmony of growth and plant productivity, and increased growth immediately increases the grass and browse available for the animals. Attention can then be turned to Utilisation. Monitoring shows when management is sound. Provided that the tranquillity of the herds can be maintained and that there are sufficient grazers and browsers, the animals use up the surplus growth and so keep down the risk of fire. Continued monitoring has not disclosed any evidence of overutilisation. It is expected, then, that a balance will be struck between the different kinds of animals and the diverse habitats in the park.

At the present time the Conservation Triangle is functioning according to plan. Regeneration and utilisation are expanding, disturbances are being reduced, while survival and amenity values increase. Travellers on their way to the Arusha park may drive through miles of open country without seeing any wild animals at all, but, once they cross the (unmarked) park boundary, elephant, giraffe, buffalo, bushbuck, waterbuck, warthog and dik-dik are immediately in evidence by the roadside. A day spent with the animals and birds in this fine lakeside and mountain scenery is a most convincing testimony to the value of conservation. 